This item was submitted to Loughborough's Research Repository by the author.

Items in Figshare are protected by copyright, with all rights reserved, unless otherwise indicated.

\title{
Extensive and intensive globalizations: explicating the low connectivity puzzle of U.S. cities using a city-dyad analysis
}

PLEASE CITE THE PUBLISHED VERSION

http://dx.doi.org/10.1111/juaf.12077

\section{PUBLISHER}

Wiley / ( U Urban Affairs Association

\section{VERSION}

AM (Accepted Manuscript)

\section{PUBLISHER STATEMENT}

This work is made available according to the conditions of the Creative Commons Attribution-NonCommercialNoDerivatives 4.0 International (CC BY-NC-ND 4.0) licence. Full details of this licence are available at: https://creativecommons.org/licenses/by-nc-nd/4.0/

\section{LICENCE}

CC BY-NC-ND 4.0

\section{REPOSITORY RECORD}

Taylor, Peter J., Michael Hoyler, Kathryn Pain, and Sandra Vinciguerra. 2019. "Extensive and Intensive Globalizations: Explicating the Low Connectivity Puzzle of U.S. Cities Using a City-dyad Analysis". figshare. https://hdl.handle.net/2134/16483. 


\title{
EXTENSIVE AND INTENSIVE GLOBALIZATIONS: EXPLICATING THE LOW CONNECTIVITY PUZZLE OF U.S. CITIES USING A CITY-DYAD ANALYSIS
}

\author{
Peter J. Taylor, Northumbria University \\ Michael Hoyler, Loughborough University \\ Kathy Pain, University of Reading \\ Sandra Vinciguerra, University of Reading
}

\begin{abstract}
This article reports an experiment in world city network analysis focusing on city-dyads. Results are derived from an unusual principal components analysis of 27,966 city-dyads across 5 advanced producer service sectors. A 2-component solution is found that identifies different forms of globalization: extensive and intensive. The latter is characterized by very high component scores and describes the more important city-dyads focused upon LondonNew York (NYLON). The extensive globalization component heavily features London and New York but with each linked to less important cities. U.S. cities score relatively high on the intensive globalization component and we use this finding to explain the low connectivities of U.S. cities in previous studies of the world city network. The two components are tentatively interpreted in worldsystems terms: intensive globalization is the process of core-making through city-dyads; extensive globalization is the process of linking core with non-core through city-dyads.
\end{abstract}


This article is about cities in globalization with specific attention paid to leading U.S. cities. It was recognized more than two decades ago that the increasing globalization of economic practices was leading to increasing importance of cities (Knight \& Gappert, 1989; Sassen, 1991; Taylor, 2013, pp. 5-6). The basic argument was provided by Sassen: the new economic dispersion of production across the world generated a consequent need for a new concentration of control and servicing. It was the enhanced relevance of these traditional urban functions in a globalizing world that turned selected cities into economic strategic places that Sassen termed "global cities." This new category of city - the archetypes were New York, London and Tokyo was characterized by a global capacity in terms of both headquarter functions and advanced producer servicing. The latter was conducted by financial, professional, and creative business service firms for whom the global city was both a market (the global corporate headquarters), and a site of production (knowledge-rich agglomerations of global-savvy banks, law firms, advertising agencies, etc.).

As well as initiating a large and growing global/world city literature (Brenner \& Keil, 2006; Derudder, Hoyler, Taylor, \& Witlox, 2012), Sassen's work inspired a predictable new urban policy demand: major cities across the world wanted to become "global cities" so as to emulate the economic successes of New York, London, and Tokyo. But which cities could realistically aspire to reach such heights? Perhaps Chicago and Los Angeles in the United States, certainly Paris in Europe, and possibly Hong Kong and Singapore in Pacific Asia. To provide more definitive answers to this question, several interested parties compiled rankings of cities to indicate how specific cities were currently faring but with a view to assessing their future potential; Hartley and his colleagues (2012, pp. 25-46) have reviewed 20 examples of such exercises. But most of this work has proceeded with a serious basic flaw: they treat cities as singular places and investigate what they contain. This is a classic example of what Jacobs (2000) in her generic studies of cities calls the erroneous "thing theory" of economic development - economic potential is not to be measured as a collection of attributes describing a location (e.g., number of corporate headquarters, proportion of workers with degrees, etc.); 
rather the key point is how such features of a city's economy relate to each other and to the wider economy. Such a relational approach is especially necessary for understanding cities in globalization where, according to Castells' (1996) seminal work, we are experiencing the rise of a global network society in which complex spaces of flows (e.g., global financial markets) are coming to dominate simpler spaces of places (e.g., the international mosaic of countries). In this article we build upon and develop a specific relational approach that defines a world city network (Taylor, 2001, 2004; Taylor, Hoyler, \& Verbruggen, 2010).

The world city network is derived from an interlocking network model that uses the office networks of advanced producer service firms. In the first section of the article this model is described along with the data collected to operationalize it. From this work we focus upon one element of the results that describe relations between individual pairs of cities. This is the city-dyad analysis of our title and constitutes the latest way in which we have been using our model. Such analysis provides a key addition to understanding cities in globalization through creation of new relational geographies. In the second section we outline how such geographies are configured from the large number of city-dyads we have measured; our tool of choice is a principal components analysis that reduces the diversity in inter-city relations to just two dimensions. These are the intensive and extensive globalizations of our title. The third and fourth sections describe and discuss the empirical output, first at the global scale and then for the particular and peculiar case of U.S. cities in globalization. Both sets of results are interesting in relation to previous research on the world city network. The specific identification of two general types of globalization within the practices of business service firms is new and contributes to understanding this economic globalization as being much more than a simple change of geographical scale in corporate organization. For U.S. cities, the findings help us understand their curious status of being relatively under-connected within the world city network (Taylor \& Lang, 2003); this is the "puzzle" referred to in our title. In a final concluding section we address the relevance of our results: the global scale 
findings are considered as having theoretical importance, and the U.S. cities findings are discussed for their practical importance.

\section{The world city "interlocking" network model}

World city network analysis draws explicitly on Saskia Sassen's (1991) work on the "global city" as a key production site and market for financial and other advanced producer services (APS). Contemporary economic globalization has been facilitated and enabled by APS firms providing specialized business services, such as in financial services, accountancy, law, management consultancy, and advertising, which offer customized financial, professional, and creative expertise to their corporate clients. In this process, many APS firms have become transnational firms in their own right as they expand into a growing global market to service their existing customers and acquire new clients (see Aharoni \& Nachum, 2000; Bryson \& Daniels, 1998). While APS firms have historically always clustered in cities, their role in contemporary globalization has necessitated multiple offices in major cities around the world. The resulting worldwide office networks enable firms to offer a "seamless" service to their corporate clients operating in international markets and thereby protect their brand integrity (i.e., by not outsourcing business; for example, the use of foreign "correspondence banks" in the past). The world city network analysis we employ here focuses on these office networks.

Each firm has its own strategy in terms of the location and number of cities in which to maintain a presence, as well as the size and functions of individual offices. It is the work done in these offices that "interlocks" the cities in which they are housed in servicing projects that require multiple office inputs. Thus the intercity relations in these servicing practices consist of both electronic and embodied flows (for example, online exchange of information and sharing of knowledge, as well as face-to-face meetings involving business travel). These "working flows," combined across numerous projects in many firms, constitute the world city network (WCN) (for detailed specification and further explication see Taylor 2001, 2004, 2012). 
The WCN can be formally represented by a city-by-firm matrix $\mathbf{V}_{i j}$, where $v_{i, j}$ is the "service value" of city $i$ to firm $j$. This service value is a measure of the importance of a city to a firm's office network, which depends on the size and functions of a firm's office (or offices) in a city.

The inter-city connectivity $r_{a-i}$ between two cities $a$ and $i$ is defined as follows:

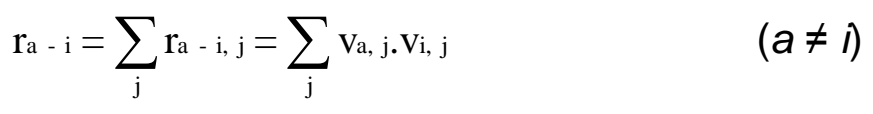

This provides a measure of the potential work flows between pairs of cities and forms the key input to our city-dyad analysis. The assumption behind conceiving the product of service values $v_{a, j} \cdot v_{i, j}$ as a surrogate $r_{a-i, j}$ for actual flows of intra-firm information and knowledge between cities $a$ and $i$ for firm $j$ is that the more important the office, the more links there will be with other offices in a firm's network (i.e., this is a simple interaction model: two cities housing large offices will generate more inter-city working flows between them than two cities with small offices).

Typically, in world city network analysis these inter-city connectivities are aggregated for each city and these totals are interpreted as the global network connectivity (GNC) of a city, indicating its overall importance within the WCN:

$$
\mathrm{GNC}_{\mathrm{a}}=\sum_{\mathrm{i}} \mathrm{r}_{\mathrm{a}-\mathrm{i}}=\sum_{\mathrm{i}, \mathrm{j}} \mathrm{V}_{\mathrm{a}, \mathrm{j}} \mathrm{V}_{\mathrm{i}, \mathrm{j}} \quad(a \neq i)
$$

To make GNC measures independent from the number of firms and cities included in a world city network analysis, GNC values are usually expressed as percentages of the largest computed GNC in the data (in most analyses this has proven to be London). Thus in our analysis below, GNC ranges from 0 (no connectivity, a city whose service firms have no offices in any other city in the data) to $100 \%$ for the most connected city (usually London). It is the GNC measures for U.S. cities that appear to show them as relatively "underconnected" in the world city network (Taylor \& Lang, 2005). 
To operationalize this model requires measurement of firms' office networks to empirically construct a city-by-firm matrix $\mathbf{V}_{i j}$ of service values. In analyses below we use the data matrix collected jointly by the Globalization and World Cities (GaWC) Research Network (www.lboro.ac.uk/gawc) and the Chinese Academy of Social Sciences (CASS) for 2008. This matrix describes the office networks of 175 advanced producer service firms across 525 cities worldwide (Derudder et al., 2010; Hanssens et al., 2011; Taylor et al., 2011). The largest firms in the following sectors are included: the top 75 in financial services, and the top 25 each in accountancy, advertising, law, and management consultancy. For each firm, its use of a city is coded from 0 (no presence) to 5 (for the city housing its headquarters) with scores of 1 through to 4 based upon size and functions of offices. The result is a "service values matrix" that arrays 525 cities against 175 firms which defines the world city network (Taylor, 2001, 2004); the methodology is further described in Taylor, Catalano, \& Walker (2002a) and Taylor et al. (2011).

The service values matrix we have analyzed is a reduced version of the above. This is because the matrix becomes very sparse (excessive zeros) with less important cities, and we know results are less robust the lower a city's GNC (Liu \& Taylor, 2011). We decided to limit the cities to those recording GNCs of $10 \%$ and above (i.e. more than $10 \%$ of London's connectivity). There are 237 cities that meet this threshold and therefore the revised service values matrix is 237 cities $\times 175$ firms; these are the prime data analyzed below.

\section{Principal components analysis of city-dyads}

The analysis we employ is principal components analysis (PCA). This is a standard technique for finding patterns in data matrices of $n$ variables and $m$ cases where both $n$ and $m$ are large (Rummel, 1970). 
Principal components analysis reduces a big data matrix into a smaller one by combining like variables into new "common variables" called components. Thus PCA results will divide the variability in the data into two parts: that identified as common, and the part constituted by particularities. The idea is to focus on the former in the hope that just a few components account for a sizeable proportion of the variation in the data matrix. Thus PCA is a tool of parsimony that excavates common patterns within multifarious data sets.

There are three key pieces of information produced in the analysis:

1. Importance of components. Components are extracted from the data in order of importance defined as proportion of variance in the matrix they encompass. The idea is to focus on just the most important components.

2. Relating variables to components. The degree of correlation between a variable and a component is given by component loadings. Loadings, like correlation coefficients, range from +1.0 to -1.0 . The idea is to focus on firms with high positive loadings on a component, commonly defined as loadings above +0.4 .

3. Relating cases to components. The significance of each case for a component is given by component scores. These are presented as standardized variables; this means they have a zero mean, and scores with high positive values are deemed to indicate cases that are particularly important in a given common component. Scores above +2 are commonly used to identify important cases for a component.

Finally, most PCAs use a varimax rotation of initial extraction of components to ensure clearly defined components called simple structure (Rummel, 1970, pp. 376-381). This clarity is vital to being able to make sense of what the components actually mean. Interpretation of components involves their labeling, for which both high loading variables are usually used, sometimes supplemented by cases with the highest scores. 
PCA is generally used as a data reduction technique, but here we use it in a more exploratory mode. In previous world city network analyses we have applied the data reduction to good effect. In these studies the input to PCA was the service values matrix treating office strategies as variables and cities as cases, thus generating patterns of "common location strategies" (Taylor, Catalano, \& Walker, 2002b; Taylor, 2011a). However, in this article we have carried out a completely new application of PCA investigation that we term city-dyad analysis. Instead of using the service values matrix as input, this is used as the source of new variables and cases. In the process of exploring our data we constructed a new and unusual matrix: both cases (cities) and variables (firms) were re-specified. First, the 237 cities were replaced by all possible pairings of the cities, resulting in 27,966 city-dyads. These values are given by equation (1). The top ten city-dyads in terms of this measurement are shown in Table 1 for illustrative purposes. Note that London-New York, the only dyad with its own name, (NYLON), is by far the most connected citydyad. Note also that all the other nine city-dyads include either London or New York in each pairing: this further underlines the dominance of these two cities within the world city network. The other cities paired off with these two include all the most likely suspects - Hong Kong, Paris, Singapore, Tokyo plus, interestingly, Shanghai.

\section{TABLE 1 ABOUT HERE}

This new definition of cases produces a 27,966 city-dyads x 175 firms matrix where each cell is created as the product of each pair of cities' service values. But this very large matrix generates new problems of matrix sparsity and robustness. Therefore, the variables have been re-specified; firms are replaced by their sectors to produce a 27,966 city-dyads x 5 sectors matrix. This was achieved by aggregating the city-dyad connectivities by sectors. Again for illustration, the results for the top ten dyads in each sector are shown in Table 2. As expected, NYLON has the highest connectivity for every sector but the degree of ascendancy varies greatly: in law it is very large, which contrasts with advertising where it all but disappears. These differences 
across sectors in the $27,966 \times 5$ matrix constitute the variability we explore through this application of principal components analysis.

\section{TABLE 2 ABOUT HERE}

It is clear now that with a $27,966 \times 5$ matrix we are not in the business of using PCA for a multivariate data reduction since we start with only five variables (the sectors). Nevertheless this long, slim matrix can still be analyzed to produce principal components, and a varimax rotation was undertaken to concentrate the variance in as few components as possible. In this case the first two components accounted for $83.41 \%$ of the total variance. This variance was split $46.50 \%$ to $36.91 \%$ between Components I and II respectively (Table 3 ). These two components are the subject matter of the rest of this article.

\section{TABLE 3 ABOUT HERE}

\section{Excavation of two globalizations}

The usual way of interpreting and labeling components is through component loadings on the variables. These are shown in Table 4. Among the loadings there are three particularly large ones: accountancy and advertising on Component I, and law on Component II. Thus if we were to label by variables, then Component I would be "accountancy-advertising" and Component II would be "law". However, the other two sectors are above the 0.4 loading threshold for both components and therefore should also be considered in the labeling process. We can note that financial services load higher on I and management consultancy on II but it is not at all clear what these further loadings are showing us; perhaps this focus on loadings is not best suited for interpretation and labeling in this analysis, given that they provide only ten items of evidence.

\section{TABLE 4 ABOUT HERE}


Turning our focus to the scores, we might expect the components to exhibit different geographies leading to simple world-regional labels as with previous studies (Taylor, 2004; Taylor et al., 2011). But this is not what shows up here; the geography that emerges is a complex interweaving across continents. In Table 5 the top twenty (out of 27,966) city-dyads are ranked by their scores for each component. These two lists show two clear differences: in the magnitude of the scores themselves, and in the actual mix of city-dyads. Starting with differences in magnitudes of the scores, the first point to make is that all the scores listed in Table 5 are large in comparison to most principal components analyses. Since scores are reported as standardized variables (mean $=0$, standard deviation $=1$ ) they are usually concentrated in the range $+/-3$ with, as noted previously, focus on those above +2 . But in this analysis we have 27,966 scores (one for each dyad) so that at the extremes (i.e., Table 5, which shows just the tail of this very large distribution of scores) we can expect some quite large values such as those reported for Component I. But the scores for Component II are another matter altogether. These exceptionally large values are measuring an unusual distribution of variables (city-dyads) constituting a component; they indicate a very intensive concentration of variance within the analyzed matrix. Of course, since both components have a mean of zero, Component Il's large scores must be compensated by lower scores than Component I in much of the remainder of the whole set of 27,966 scores. The point where the distribution of scores in the two components cross over is shown in Figure 1: it is at rank 278 with scores just above 3.7. It is the "take-off" of the Component II graph from this point that defines a very distinctive concentration in the tail of the frequency distribution of this component.

\section{TABLE 5 ABOUT HERE}

\section{FIGURE 1 ABOUT HERE}

It was this unusual nature of Component Il's distribution of scores that led us to first consider labeling the component as intensive globalization (Figure 2). 
This idea was strongly supported when reviewing the differences between the two components in terms of actual city-dyads in Table 5. The first point to note is that London and New York dominate both lists of city-dyads and there is little disparity in numbers between the components: they are members of 16 dyads for Component I and 18 for Component II. The main difference is therefore in the partners of the two leading cities. And it is significant to note that eight of the top ten dyads from Table 1 are listed under Component II including NYLON itself, and none under Component I. But Component II is not a simple mix of the most highly connected city-dyads: dyads featuring two new cities, Frankfurt and Washington, are prominent. In fact both components include numerous Asian and European cities, but with clear differences. In both continents Component II includes more important city partners than Component I: for instance, in Asia Component II focuses on Chinese and Japanese cities and Component I includes Seoul, Kuala Lumpur and Mumbai; and in Europe it includes Paris, Frankfurt, and Brussels, which contrasts markedly with Athens, Dublin, and Istanbul for Component I. Thus statistical concentration on high scores is complemented by urban concentration on more important cities to indicate further Component II as intensive globalization. But to confirm this we need to consider the geographies of both Component I and Component II dyads.

Figure 2 features the top 50 city-dyads for Component II. The geography of these dyads is quite stark: they only link cities in three world regions, Northern America (United States plus Canada), Europe, and Pacific Asia. These regions have previously been identified as the three "globalization arenas" from which contemporary globalizing processes originated (Beaverstock, Smith, \& Taylor, 2000; Taylor et al., 2011). This geographical concentration confirms Component Il's label as intensive globalization. As a counterpoise, and using Figure 3, we can label Component I as extensive globalization. This figure illustrates the top 50 city-dyads for the latter component and shows a much more extensive geography. From Table 5 we previously noted that this component tends to include less important cities, and in Figure 3 this translates into a geography including Buenos Aires, Johannesburg, Jeddah, Mumbai, and Sydney to provide a worldwide distribution. This intensive- 
extensive contrast is clearly confirmed when we consider the top 100 citydyads for each component and their distribution within and between the three globalization arenas and the rest of the world (Table 6 ). Whereas the majority of intensive globalization city-dyads are between cities in different globalization arenas, most extensive globalization city-dyads include cities from beyond the globalization arenas. There are also large differences between intensive and extensive globalizations with respect to city-dyads that include both cities from the same globalization arena: the ratio is nearly two to one in favor of the former.

FIGURE 2 ABOUT HERE

FIGURE 3 ABOUT HERE

\section{TABLE 6 ABOUT HERE}

We can now return to the loadings in Table 4 to understand the process behind these two globalization patterns. Basically, it is legal services that indicate intensive globalization. Major law firms helping their clients navigate multiple jurisdictions are concentrated in London and New York (Faulconbridge, 2007). Typically, they have relatively small office networks to service clients in other leading financial and political centers. This strategic approach to globalization is also shared by financial services and management consultancy, but to a much lesser extent (Table 4). This is because some firms in these sectors also tend to have much larger office networks related to extensive globalization. For instance, within financial services, specialist investment banks develop their financial instruments in major financial centers, whereas more general banks and insurance companies are especially concerned about working in broader markets. The latter is the hallmark of accountancy and advertising firms (Table 4). Accountancy firms generally have the largest office networks, sometimes numbering thousands. Advertising agencies try and cover all major national markets; they target cities with the main TV centers, usually the capital city but not always so (see Sydney, Mumbai, Milan, Shanghai, Istanbul, Jeddah, Tel Aviv, Zurich, and Auckland in Figure 3). Thus, extensive globalization is 
created by firms who are operating worldwide to market their products, whereas intensive globalization results from firms needing to concentrate their work in leading cities and regions.

There are seven cities that appear on both Figures 2 and 3: they are part of both extensive and intensive globalization. As well as London and New York, there is one European city, Paris, plus four from Pacific Asia - Hong Kong, Tokyo, Singapore, and Shanghai. We can interpret these seven cities as acting as a hinge or conduit between extensive and intensive globalizations. It seems that alone among cities of "emerging economies," it is China, with Hong Kong and Shanghai, that is carving out such a role. We have had a premonition of this happening: in analysis of previous GaWC data for 2004, Taylor (2006a) found Beijing and Shanghai in a class of their own, linking together groups of more and less important cities. In this analysis it appears that Hong Kong and Shanghai are embarked on a distinctive path, perhaps leading towards an alternative to NYLON in articulating the world city network between extensive and intensive globalizations.

\section{A solution to the low global network connectivity puzzle of U.S. cities}

Having excavated these two globalizations, we have found that they can be used to help solve an enduring puzzle from previous world city network analyses: the relatively low GNCs of U.S. cities, excepting New York. This was first noted by Taylor and Lang (2005) in their study of U.S. cities in the world city network based upon GaWC 2000 data. Their second finding was that "US cities overall - and particularly non-coastal cities - are generally less globally connected than their European Union and Pacific Asian counterparts" (p. 1). This finding was based upon measures of global network connectivity as given in equation (2). It has been repeated in analyses of GaWC 2004 data (Taylor \& Aranya, 2008) and GaWC 2008 data (Derudder et al., 2010; Taylor, 2011a). But these GaWC analyses appear alone in this relative low ranking of U.S. cities globally: other global analyses of inter-city relations generally show a much more important role for U.S. cities than we find: see for example, 
Alderson and Beckfield (2004) using corporate headquarters and branches (factories, offices, etc.), Smith and Timberlake (2001) on global air travel links, and Malecki (2002) on the Internet's infrastructure. This is not a question of which method of measuring the importance of cities is right and which is wrong. Rather the different methods are trying to represent different city network processes (Taylor, 2006b). As previously described, in the GaWC analyses, the process being modeled is Sassen's (1991) original specification of the "global city," focusing on advanced producer services, extended to define an interlocking city network. Thus the question is reformulated as to why this particular networked "global city" servicing process is relatively weak amongst U.S. cities excepting New York.

To answer this question, another, closely related finding has been brought into the argument. If just connections to "local" cities are considered (e.g. U.S. city relations to other U.S. cities; EU city relations to other EU cities), it is found that U.S. cities are exceptionally "local" compared to cities in other regions or countries (Taylor \& Lang, 2005, p. 9) and this was especially so in 2008 (Taylor, 2011b, pp. 333-334). Therefore it follows that the United States appears to be operating as a distinctive market for advanced producer services within the wider world market. Taylor and Lang $(2005,11)$ give two reasons for this: a "shadow effect" caused by many non-U.S. service firms locating only in New York, and a "comfort effect" caused by many U.S. service firms not wanting to leave their large "home market" for riskier foreign investments. This has been most recently depicted as a case of American exceptionalism within the world city network (Vinciguerra, Taylor, Hoyler, \& Pain, 2010). But all these findings and interpretations have been predicated on analyses with single cities as objects, not city-dyads. Our new analysis casts fresh light on the low connectivities puzzle of U.S. cities.

In the intensive globalization map (Figure 2), New York is not the only U.S. city: Washington, Chicago, and Los Angeles also feature. We can explore this further by searching out more U.S. cities that have relatively high scores on the two components. Conventionally in principal components analysis, the researcher focuses on scores above +2.0 . However, as noted earlier for this 
analysis, because of the size of the matrix, there are large numbers of citydyads with scores above this threshold: 3,686 such city-dyads for extensive globalization and 1,329 city-dyads for intensive globalization. (Note that this large difference in numbers does provide further support for our labeling of the two components: by this definition Component $I$ is nearly three times more "extensive" than Component II.) We have located all U.S. cities in the 1,329 city-dyads above 1.0 in Component II. To provide equity in comparison, we have used the same number of city-dyads for searching out U.S. cities in Component I. The results of these two searches are shown in Figure 4. There are three basic findings:

1. Of the 27 cities featured, only five are members of extensive globalization city-dyads: New York, Chicago, Atlanta, Los Angeles, and San Francisco. It is these cities that are primarily responsible for U.S. involvement in extensive globalization. However, in each case these dyads constitute a minority of the city's total dyads, with New York coming closest to parity with inclusive globalization.

2. It follows that there are 22 cities that are members of only intensive globalization dyads in Figure 4. These include major metropolises such as Boston, Philadelphia, Washington, Dallas, and Houston.

3. There is a huge empty space in this portrayal of globalization through world city networking in the United States. It stretches from northern to southern boundaries between Minneapolis/Chicago and Texas through to the Pacific coast: important U.S. cities such as Denver, St Louis, and Kansas City are conspicuous by their absence from Figure 4 .

The third finding indicates a dearth of global networking processes in a middle section of the country; we will not dwell on this further. Our interest is in the way U.S. cities are connected into the world city network, and therefore our discussion will focus on the first two findings above.

FIGURE 4 ABOUT HERE 
The propensity for U.S. cities to be members of intensive globalization citydyads runs counter to the city-dyads previously reported in the global scale results. In the intensive globalization map (Figure 2) it is the leading world cities around the world that are picked out, with the extensive globalization map (Figure 3) featuring numerous less important cities globally. In the United States it appears that only the most important cities feature in extensive globalization city-dyads, so that here it is intensive globalization dyads that are dominated by many less important cities. This does not simply support previous arguments for U.S. exceptionalism in the world city network; it implies a sort of inversion of how globalization plays out in the United States compared to the rest of the world. It is this intriguing situation that is brought to bear on the puzzle of why U.S. cities appear to be generally underconnected in world city network analyses.

We suggest the following argument provides a new insight into the U.S. cities' low global network connectivities puzzle.

A. In terms of cities in globalization, there are two main processes generating the world city network.

B. U.S. cities are largely part of the second process, intensive globalization, and, with the exception of New York, do not feature greatly in extensive globalization.

C. But measures of global network connectivity do not recognize the two processes; this measure combines the outcomes of both processes.

D. However, unlike the principal components analysis where each sector as a variable is equally weighted, in measuring global network connectivities the contribution of a sector depends on the overall number of offices (and their weightings) in that sector.

E. Accountancy and advertising firms have far more offices across the world than law firms and therefore contribute far more to measures of global network connectivity.

F. Therefore, because accountancy and advertising sectors are the main creators of extensive globalization and the law sector is the main 
creator of intensive globalization, it is the former globalization that is represented to a far greater degree in global network connectivity.

G. Hence, because U.S. cities are particularly strong on intensive globalization, overall they do not figure as prominently as might be expected in global network connectivities.

This argument does not negate Taylor and Lang's (2005) explanations previously described; indeed it might encompass them, but it does specify a new logic based upon the new knowledge, that is, the excavation of extensive and intensive globalizations through city-dyad analysis.

\section{Concluding remarks}

The analysis reported here is our first use of a research design that highlights city-dyads rather than cities per se in the world city network. As such its importance is two-fold. The global-level results inform theoretical debates on how globalization is constituted spatially, specifically in relation to coreperiphery models of the world-economy. The findings for U.S. cities have a more practical relevance, specifically introducing American exceptionalism into the matter of framing urban policy under conditions of globalization. We consider each in turn.

Uncovering two distinctive globalization processes opens up suggestions for some fresh thinking about the structure of today's globalizing world economy. Consider, for instance, the implications of a single geography of cities in globalization being replaced by two geographies of city-dyads in globalization. The prior notion of three main "globalization arenas" - Northern America (mainly the United States), Europe (mainly the EU) and Pacific Asia - has to be rethought. The two globalization processes are to be found in each of these regions, but in quite distinctive ways. The intensive globalization is predicated upon NYLON and encompasses more important city-dyads than extensive globalization, but the latter compensates by being present beyond the key globalization arenas. The most difficult feature of this dyad geography 
is the dual roles of London and New York. These cities dominate both geographies but in quite different ways: within intensive globalization integrated as NYLON, in contrast to the two unconnected "prime nodes" in Figure 3 suggesting London versus New York within extensive globalization. Such ideas indicating two opposing processes operating through the "global twin-cities" (or "the New York-London axis"; Wójcik, 2013) requires further investigation using qualitative research strategies to show how and why advanced producer service firms use city-dyads differently.

Without the latter follow-up research, we can only speculate what our finding of two globalizations through city-dyad analysis actually means. However their distinctive natures as extensive and intensive, and with the latter centered on NYLON, both suggest power differentials operating within the world city network (Allen, 2010). Thus we might identify intensive globalization, in worldsystems analysis terms, as a strong core-making process, and extensive globalization as integrating core processes with non-core processes (semiperipheral cities and periphery beyond). Core-periphery models are often criticized for being overtly simple and therefore being transcended by contemporary globalization processes (Scott, 2012, pp. 52-62); this new interpretation is suggestive of a complexity in a new contemporary coreperiphery structure of the world-economy through city-dyads.

In terms of U.S. exceptionalism in the world city network, the new city-dyads analysis has a practical relevance on several levels. As suggested in the introduction, ever since Sassen's (1991) seminal identification of "global cities," urban policy makers in major metropolitan areas have been presented with new goals for their cities as a consequence of globalization. However, our analysis reinforces the tendency not to treat globalization as a single overarching process but to view it as a bundle of myriad processes. In terms of cities our results make the very basic point that policy makers should be taking into account two globalizations rather than one, understanding that there are two processes, distinctive in both content and geography. And American exceptionalism is central to their distinction. However the key levels 
for considering practical implications of our results concerns business practice within U.S. city economies.

The economic success of a city ultimately depends on the firms working in the city, their resilience and their dynamism. These depend on such features, respectively, as sectoral diversification of firms within the city, and having a good share of firms in cutting edge sectors. The advanced producer service firms used in this study are in a cutting edge knowledge-based sector, but they further indicate a city's geographical diversification of economic relations. The interlocking network model's specification of global network connectivity is a measure of a city's global capacity. Put simply, it shows the ease of doing business globally from a given city. The city-dyad analysis adds a further refinement: global capacity is understood as dual competences, intensive and extensive. The fact that U.S. exceptionalism is reflected in most U.S. cities' capabilities being firmly intensive is particularly relevant to urban policy. It means they are privileged by their U.S. location to be integrated in a globalizing process that includes the more important world cities across the three main globalization arenas. But contemporary importance reflects recent past successes, and relying on their future continuity may be rather complacent. Thus it could be highly relevant that U.S. cities are missing global capacity extensively in regions beyond these three arenas. In today's upheavals of a continuously globalizing economy, it looks increasing likely these other regions will become much more important in the twenty-first century. But it is here that U.S. cities are conspicuously underprivileged in their global capacity. Any economic development agency within U.S. cities should address this issue as a priority.

\section{Acknowledgement}

This work was supported by the UK's Economic and Social Research Council [Grant number RES-000-22-3573], "Benchmarking the World City Network." 


\section{References}

Aharoni, Y., \& Nachum, L. (2000). Globalization of services: some implications for theory and practice. London: Routledge.

Alderson, A., \& Beckfield, J. (2004). Power and position in the world city system. American Journal of Sociology, 109, 811-851.

Allen, J. (2010). Powerful city networks: More than connections, less than domination and control. Urban Studies, 47, 2895-2911.

Beaverstock, J. V., Smith, R. G., \& Taylor, P. J. (2000). World-city network: A new metageography? Annals of the Association of American Geographers, 90, 123-134.

Brenner, N., \& Keil, R. (Eds.) (2006). The global cities reader. London: Routledge.

Bryson, J., \& Daniels, P. W. (Eds.) (1998). Service industries in the global economy. Cheltenham, UK: Edward Elgar.

Castells, M. (1996). The rise of the network society. Oxford: Blackwell.

Derudder, B., Hoyler, M., Taylor, P. J., \& Witlox, F. (Eds.) (2012). International handbook of globalization and world cities. Cheltenham, UK: Edward Elgar.

Derudder, B., Taylor, P. J., Ni, P., de Vos, A., Hoyler, M., Hanssens, H., Bassens, D., Huang, J., Witlox, F., Shen, W., \& Yang, X. (2010). Pathways of change: shifting connectivities in the world city network, 2000-08. Urban Studies, 47, 1861-1877.

Faulconbridge, J. R. (2007). Relational networks of knowledge production in transnational law firms. Geoforum, 38, 925-940.

Hanssens, H., Derudder, B., Taylor, P. J., Hoyler, M., Ni, P., Huang, J., Yang, X., \& Witlox, F. (2011). The changing geography of globalized service provision, 2000-2008. The Service Industries Journal, 31, 2293-2307.

Hartley, J., Potts, J., MacDonald, T., Erkunt, C., \& Kufleitner, C. (2012). Creative city index: Final report. Brisbane: ARC Centre of Excellence for Creative Industries and Innovation.

Jacobs, J. (2000). The nature of economies. New York: Vintage.

Knight, R. V., \& Gappert, G. (Eds.) (1989). Cities in a global society. Newbury Park, CA: Sage. 
Liu, X., \& Taylor, P. J. (2011). A robustness assessment of GaWC global network connectivity rankings. Urban Geography, 32, 1227-1237.

Malecki, E. J., (2002). The economic geography of the Internet's infrastructure. Economic Geography, 78, 399-424.

Rummel, R. J. (1970). Applied factor analysis. Evanston, IL: Northwestern University Press.

Sassen, S. (1991). The global city. New York, London, Tokyo. Princeton, NJ: Princeton University Press.

Scott, A. J. (2012). A world in emergence: cities and regions in the $21^{\text {st }}$ century. Cheltenham, UK and Northampton, MA: Edward Elgar.

Smith, D. A., \& Timberlake, M. (2001). World city networks and hierarchies: an empirical analysis of global air travel links. American Behavioral Scientist, 44, 1656-1678.

Taylor, P. J. (2001). Specification of the world city network. Geographical Analysis, 33, 181-194.

Taylor, P. J. (2004). World city network: a global urban analysis. London: Routledge.

Taylor, P. J. (2006a). Shanghai, Hong Kong, Taipei and Beijing in the world city network: positions, trends and prospects. GaWC Research Bulletin 204. Available at http://www.lboro.ac.uk/gawc/rb/rb204.html, accessed January 31, 2012.

Taylor, P. J. (2006b). Parallel paths to understanding global inter-city relations. American Journal of Sociology, 112, 881-894.

Taylor, P. J. (2011a). Advanced producer services in the world economy. In P. J. Taylor, P. Ni, B. Derudder, M. Hoyler, J. Huang \& F. Witlox (Eds.), Global urban analysis: a survey of cities in globalization (pp. 22-39). London: Earthscan.

Taylor, P. J. (2011b). Global synthesis: national and sub-regional contrasts. In P. J. Taylor, P. Ni, B. Derudder, M. Hoyler, J. Huang \& F. Witlox (Eds.), Global urban analysis: a survey of cities in globalization (pp. 331-336). London: Earthscan.

Taylor, P. J. (2012). The interlocking network model. In B. Derudder, M. Hoyler, P. J. Taylor \& F. Witlox (Eds.), International handbook of 
globalization and world cities (pp. 51-63). Cheltenham, UK: Edward Elgar.

Taylor, P. J. (2013). Extraordinary cities: Millennia of moral syndromes, worldsystems and city/state relations. Cheltenham, UK: Edward Elgar.

Taylor, P. J., \& Aranya, R. (2008). A global "urban roller coaster"? Connectivity changes in the world city network, 2000-2004. Regional Studies, 42, 1-16.

Taylor, P. J., Catalano, G., \& Walker, D. R. F. (2002a). Measurement of the world city network. Urban Studies, 39, 2367-2376.

Taylor, P. J., Catalano, G., \& Walker, D. R. F. (2002b). Exploratory analysis of the world city network. Urban Studies, 39, 2377-2394.

Taylor, P. J., Hoyler, M., \& Verbruggen, R. (2010). External urban relational process: introducing central flow theory to complement central place theory, Urban Studies, 47, 2803-2818.

Taylor, P. J., \& Lang, R. E. (2005). US Cities in the world city network. Washington, DC: The Brookings Institution.

Taylor, P. J., Ni, P., Derudder, B., Hoyler, M., Huang, J., \& Witlox, F. (Eds.) (2011). Global urban analysis: a survey of cities in globalization. London: Earthscan.

Vinciguerra, S., Taylor, P. J., Hoyler, M., \& Pain, K. (2010). Contemporary Mappa Mundi: American exceptionalism in the world city network. Environment and Planning A, 42, 1271-1272.

Wójcik, D. (2013). The dark side of NY-LON: financial centres and the global financial crisis. Urban Studies. doi:10.1177/0042098012474513. 
Table 1 The top ten city-dyads, 2008

\begin{tabular}{|c|l|c|}
\hline & \multicolumn{1}{|c|}{ City-dyads } & Dyad connectivity \\
\hline 1 & London-New York & 1,731 \\
\hline 2 & Hong Kong-London & 1,390 \\
\hline 3 & Hong Kong-New York & 1,372 \\
\hline 4 & New York-Paris & 1,363 \\
\hline 5 & London-Paris & 1,356 \\
\hline 6 & New York-Tokyo & 1,237 \\
\hline 7 & London-Singapore & 1,234 \\
\hline 8 & New York-Singapore & 1,219 \\
\hline 9 & London-Tokyo & 1,193 \\
\hline 10 & London-Shanghai & 1,132 \\
\hline
\end{tabular}


Table 2 Disaggregation of top ten city-dyad connectivities by sectors

\begin{tabular}{|l|c|c|c|c|c|}
\hline \multicolumn{1}{|c|}{ City-dyad } & Accountancy & Advertising & $\begin{array}{c}\text { Financial } \\
\text { services }\end{array}$ & Law & $\begin{array}{c}\text { Management } \\
\text { consultancy }\end{array}$ \\
\hline London-New York & 344 & 296 & 547 & 326 & 218 \\
\hline Hong Kong-London & 336 & 212 & 540 & 186 & 116 \\
\hline $\begin{array}{l}\text { Hong Kong-New } \\
\text { York }\end{array}$ & 254 & 281 & 486 & 169 & 182 \\
\hline New York-Paris & 239 & 295 & 407 & 221 & 201 \\
\hline London-Paris & 306 & 217 & 424 & 255 & 154 \\
\hline New York-Tokyo & 206 & 282 & 448 & 135 & 166 \\
\hline London-Singapore & 317 & 204 & 470 & 102 & 141 \\
\hline New York-Singapore & 240 & 270 & 428 & 90 & 191 \\
\hline London-Tokyo & 263 & 214 & 451 & 144 & 121 \\
\hline London-Shanghai & 283 & 183 & 426 & 126 & 114 \\
\hline
\end{tabular}


Table 3 Total Variance Explained

\begin{tabular}{|l|r|r|r|r|r|r|r|r|r|}
\hline \multirow{4}{*}{ Comp } & \multicolumn{4}{|c|}{ Loadings } & \multicolumn{3}{|c|}{$\begin{array}{r}\text { Extraction Sums of Squared } \\
\text { Initial Eigenvalues }\end{array}$} & \multicolumn{3}{c|}{ Rotation Sums of Squared } \\
Total & \% of Var & Cum \% & Total & \% of Var & Cum \% & Total & \% of Var & Cum \% \\
\hline 1 & 3.456 & 69.117 & 69.117 & 3.456 & 69.117 & 69.117 & 2.325 & 46.497 & 46.497 \\
2 & .715 & 14.291 & 83.408 & .715 & 14.291 & 83.408 & 1.846 & 36.911 & 83.408 \\
3 & .404 & 8.087 & 91.495 & & & & & & \\
4 & .243 & 4.859 & 96.354 & & & & & & \\
5 & .182 & 3.646 & 100.000 & & & & & & \\
\hline
\end{tabular}


Table 4 Component loadings on service sectors

\begin{tabular}{|l|c|c|}
\hline \multicolumn{1}{|c|}{ Service sector } & Component I & Component II \\
\hline Accountancy & 0.894 & 0.241 \\
Advertising & 0.893 & 0.256 \\
Financial Services & 0.691 & 0.597 \\
Law & 0.161 & 0.911 \\
Management Accountancy & 0.473 & 0.732 \\
\hline
\end{tabular}


Table 5 Top twenty scores for each component

\begin{tabular}{|c|l|c|l|c|}
\hline \multicolumn{1}{|c|}{ City-dyad } & $\begin{array}{c}\text { Component } \\
\text { I scores }\end{array}$ & \multicolumn{1}{|c|}{ City-dyad } & $\begin{array}{c}\text { Component II } \\
\text { scores }\end{array}$ \\
\hline 1 & London-Seoul & 7.34 & London-New York & 35.96 \\
\hline 2 & New York-Seoul & 7.11 & London-Paris & 27.46 \\
\hline 3 & London-Mumbai & 7.10 & New York-Paris & 25.29 \\
\hline 4 & Kuala Lumpur-London & 6.83 & Frankfurt-London & 22.76 \\
\hline 5 & Buenos Aires-New York & 6.79 & New York-Washington & 22.31 \\
\hline 6 & Buenos Aires-London & 6.72 & Frankfurt-New York & 21.59 \\
\hline 7 & Hong Kong-Seoul & 6.66 & Hong Kong-New York & 20.01 \\
\hline 8 & Mumbai-New York & 6.63 & Hong Kong-London & 19.95 \\
\hline 9 & London-Sydney & 6.57 & London-Washington & 17.65 \\
\hline 10 & Dublin-London & 6.43 & Brussels-London & 16.69 \\
\hline 11 & Kuala Lumpur-New York & 6.38 & New York-Tokyo & 16.38 \\
\hline 12 & London-Toronto & 6.36 & London-Tokyo & 16.08 \\
\hline 13 & Athens-New York & 6.36 & Beijing-New York & 15.73 \\
\hline 14 & New York-Toronto & 6.28 & Beijing-London & 15.58 \\
\hline 15 & Seoul-Tokyo & 6.02 & Frankfurt-Paris & 15.42 \\
\hline 16 & Istanbul-New York & 6.00 & Hong Kong-Paris & 14.48 \\
\hline 17 & Seoul-Singapore & 5.97 & London-Moscow & 14.33 \\
\hline 18 & Hong Kong-Mumbai & 5.96 & London-Shanghai & 14.09 \\
\hline 19 & Athens-London & 5.91 & Moscow-New York & 13.60 \\
\hline 20 & Dublin-New York & 5.91 & Brussels-New York & 13.48 \\
\hline
\end{tabular}


Table $6 \quad$ City-dyads with the top 100 scores for extensive and intensive globalization distributed by globalization arenas

\begin{tabular}{|l|c|c|}
\hline City-dyad geographies & $\begin{array}{c}\text { Intensive } \\
\text { globalization }\end{array}$ & $\begin{array}{c}\text { Extensive } \\
\text { globalization }\end{array}$ \\
\hline Within globalization arenas: & 7 & 1 \\
Northern America & 30 & 6 \\
Europe & 6 & 16 \\
Pacific Asia & 43 & 23 \\
\hline TOTAL & 25 & 6 \\
\hline Between globalization arenas: & 10 & 7 \\
Northern America-Europe & 21 & 12 \\
Northern America- Pacific Asia & 56 & 25 \\
Europe-Pacific Asia & & 2 \\
\hline TOTAL & 0 & 12 \\
\hline Beyond globalization arenas: & 1 & 19 \\
Within the rest of the world & 0 & 19 \\
Northern America - Rest of the world & 0 & 52 \\
Europe - Rest of the World & 1 & \\
Pacific Asia - Rest of the World & & \\
\hline TOTAL & & \\
\hline
\end{tabular}


Figure 1 The "take-off" of Component II scores

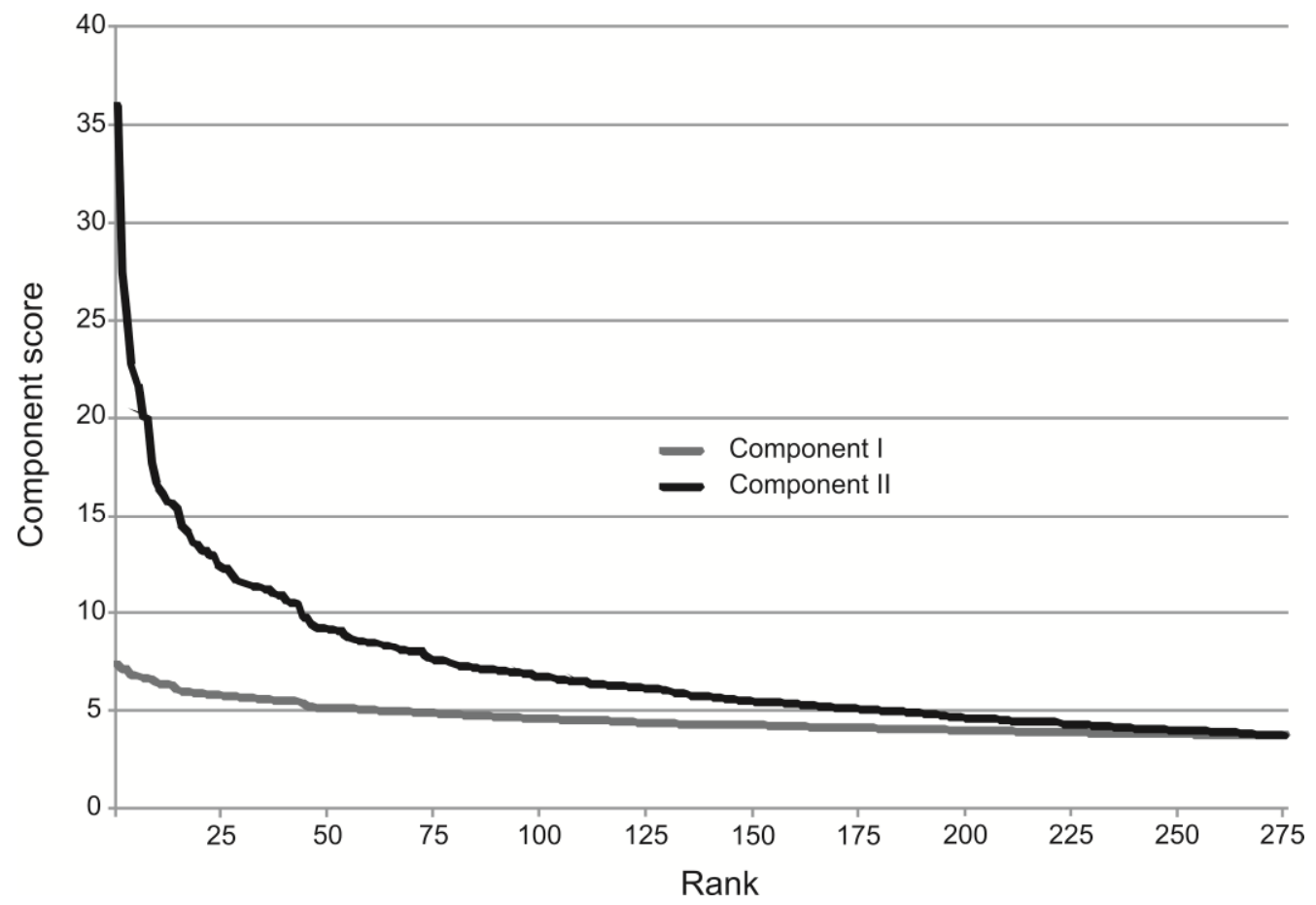


Figure 2 Intensive globalization: top 50 city-dyads for Component II

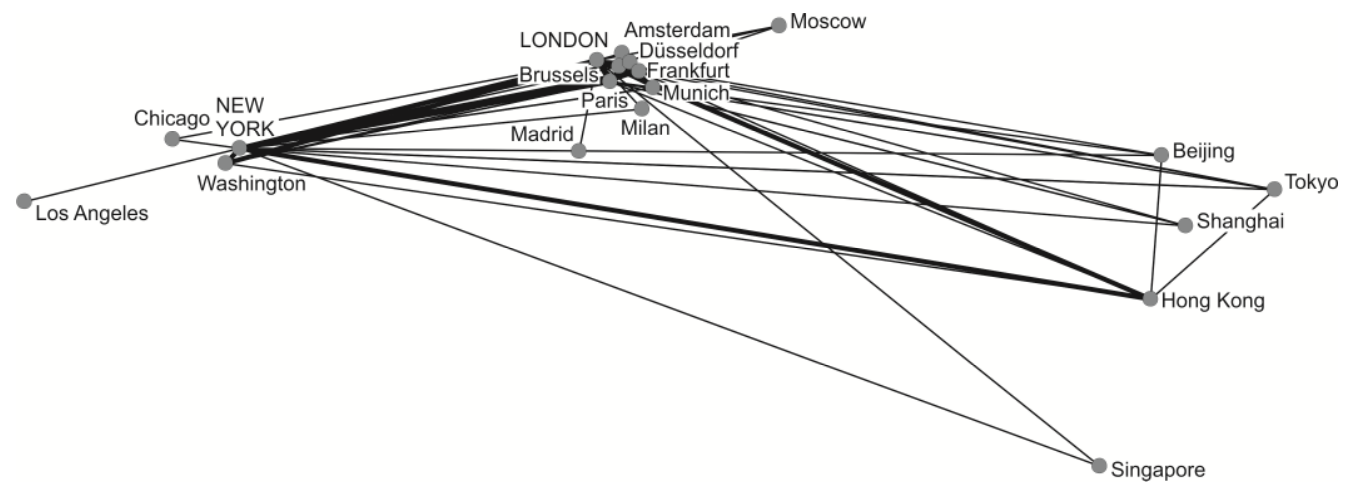


Figure 3 Extensive globalization: top 50 city-dyads for Component I

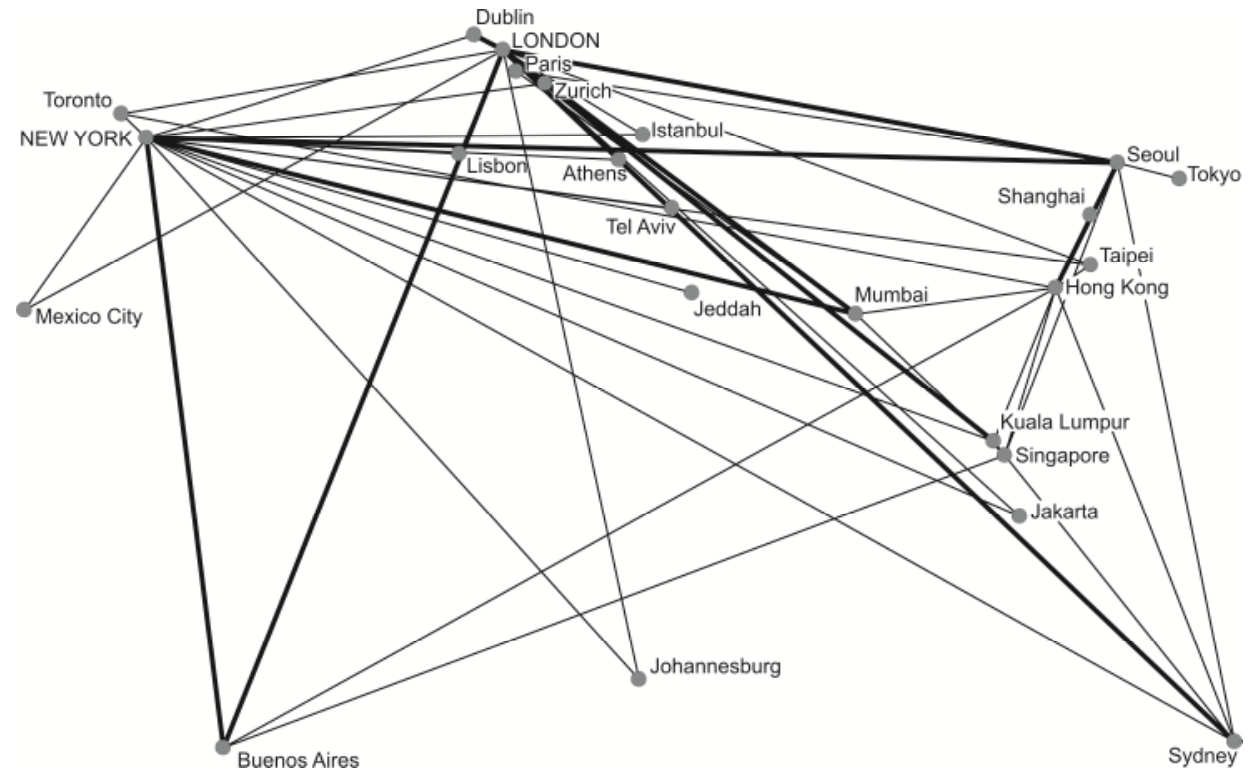


Figure 4 U.S. cities in intensive and extensive globalization

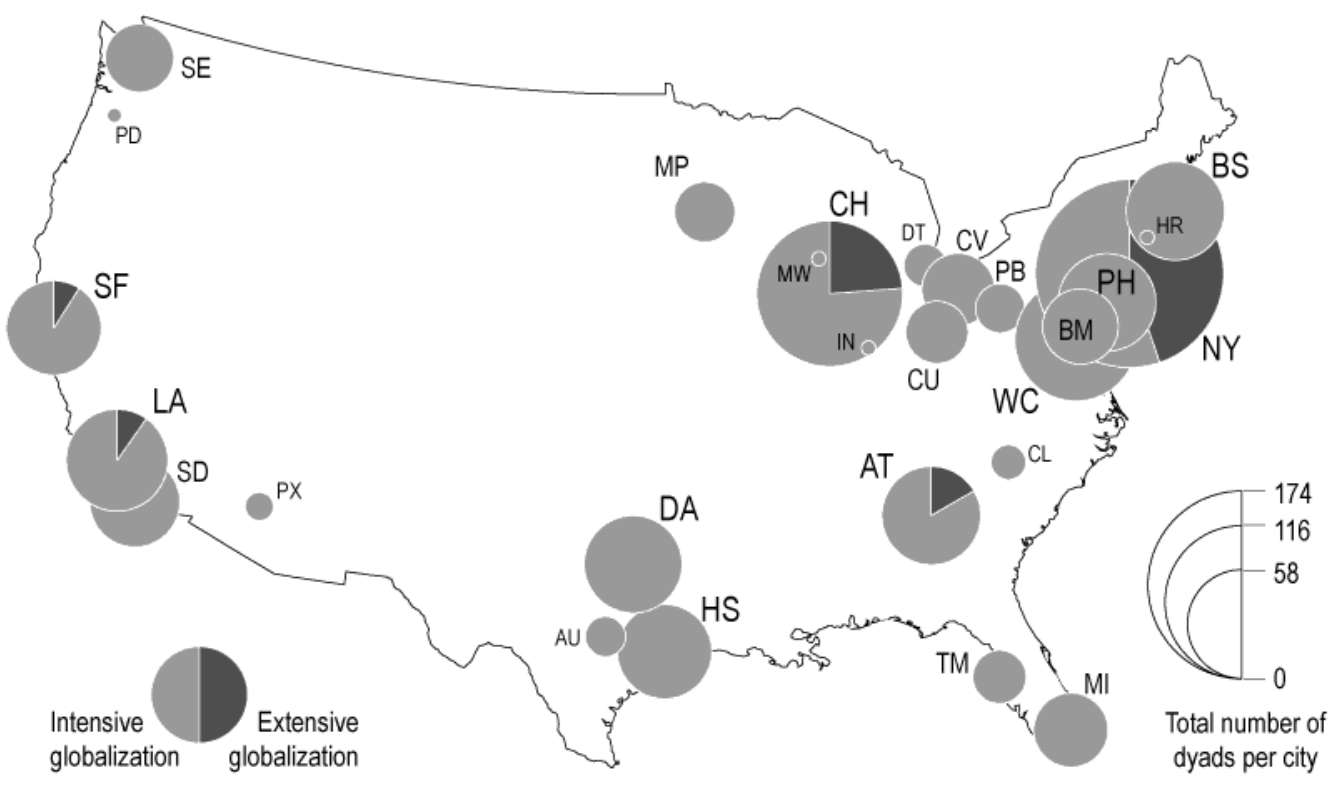

City codes: AT Atlanta, AU Austin, BM Baltimore, BS Boston, CH Chicago, CL Charlotte, CU Columbus, CV Cleveland, DA Dallas, DT Detroit, HR Hartford, HS Houston, IN Indianapolis, LA Los Angeles, MI Miami, MP Minneapolis, MW Milwaukee, NY New York, PB Pittsburgh, PD Portland, PH Philadelphia, PX Phoenix, SD San Diego, SE Seattle, SF San Francisco, TM Tampa, WC Washington DC 